\title{
Diversity of Bacteria and Fungi Associated with Freshwater Fishes from Mijawal River, Nasarawa, Nigeria
}

\section{1, 2*ADAMU, KM; ${ }^{1}$ MUHAMMAD, H; ${ }^{2}$ AHMAD, SU ; ${ }^{2}$ AHMAD, MM $;{ }^{2}$ YAKUBU, AM}

\author{
${ }^{I}$ Department of Biological Sciences, Ibrahim Badamasi Babangida University, Lapai, Niger State, Nigeria \\ ${ }^{2}$ Department of Zoology, Nasarawa State University, Keffi, Nassarawa State, Nigeria \\ *Corresponding Author Email: kabrmoh@yahoo.com; Tel: +234(0) 8035826075
}

\begin{abstract}
Understudying the presence of bacteria and fungi population on freshwater fishes, provides the knowledge and understanding of their diversity and potential roles they may play in the health of the aquatic and terrestrial ecosystems. The present study was conducted to evaluate the diversity of bacteria and fungi species of identified fish samples from River Mijawal, Nasarawa State. The fishes were sampled from the only landing for three months (October to December, 2019) for this study. During the sampling periods, thirteen (13) different fish species were identified; they were swabbed with sterilized swab stick from the skin surface for bacteria and fungi identification. The Dominant fish species were Tilapia zillii, Labeo senegalensis, Mormyrus rume and Mormyrus tapines. The total number of thirteen (13) bacterial and five (5) fungi species were isolated and identified. Eight (8) of the bacteria isolates, were gram negative bacteria (Pseudomonas sp, Aeromonas sp, Serratia mercescenes, Proteus sp, Salmonella spp, Escherichia coli, Klebsiella sp, and Enterobacter sp.); whilst the other five (5) were gram positive bacteria (Bacillus sp, Micrococcus sp, Staphylococcus sp, Enterococcus sp and Listeria monocytogenes).The five isolated fungi species were Aspergillus niger, Rhizopus sp, Penicillium sp, Trichoderma viridae and Geotrichum candidum. The frequency of occurrence of the isolated bacteria indicated that Staphylococcus $s p$ had the highest frequency of occurrence $(16.67 \%)$ while Serratia mercescens had the least occurrence $(2.78 \%)$. The highest number of occurrence of the isolated fungi species was observed in Rhizopus sp while the least was recorded in Geotricum candidum. It was observed that Tilapia zillii and Mormyrus rume had the most frequent bacteria and fungi isolates. It can therefore be deduced from the results that fish samples identified from River Mijawal has high bacteria and fungi diversity that may be pathogenic to man. The occurrence of these microbes may be attributed of human and animal faeces in the River
\end{abstract}

\section{DOI: $\underline{\text { https://dx.doi.org/10.4314/jasem.v24i6.22 }}$}

Copyright: Copyright (C) 2020 Arthi et al. This is an open access article distributed under the Creative Commons Attribution License (CCL), which permits unrestricted use, distribution, and reproduction in any medium, provided the original work is properly cited.

Dates: Received: 21 April 2020; Revised: 26 May 2020; Accepted: 20 June 2020

Keywords: Freshwater fishes, Microbes, River Mijawal, Nasarawa

Fishes are the most important protein sources for people of many countries (Hussain et al., 2011); however, they are faced with severe decline globally due to economic and human population growth (Limburge et al., 2011). The natural aquatic systems have witnessed changes in stock diversity and abundance, genetic structure and age composition of stocks resulting from structural changes in habitat, food composition and uncontrolled exploitation. The presence of foodborne pathogens in fish is related to environmental conditions and microbiological quality of the water at the fishing site. On the other hand, the microbial diversity of freshwater or Rivers and Lakes may consist of complex flora of microorganisms, including genuinely aquatic pathogens and other components introduced from human, animal and plant sources (Adams and Tobias, 1999); as the scale of human activities has been demonstrated to exert some detrimental effects on coastal waters. Diseases in freshwater fishes are of great threat in achieving optimum production and have become a limiting factor to economic success of aquaculture. Bacterial infections are the major constraint for rapid cultivation of these species as it is believed that contaminated water is one of the root causes for the origin of bacterial-borne infection in fishes. Several studies have shown that bacteria belonging genera Aeromonas, Corynebacterium, Myxobacterium, Pseudomonas and Vibrio cause infectious diseases in fish (Cahill, 1990). FAO (2009), reported that the level of contamination of a fish at the time of its capture, depends on the environment and the microbiological quality of the water in which it was harvested. Studies have also shown that fish are host to bacteria species as they are the most causative agents of fish diseases (Musefiu et al., 2011; Jimoh et al., 2014; Anyanwu et al., 2015; Olugbojo and Ayoola, 2015). Fungi on the other hand, are known to be responsible for a number of diseases in freshwater fishes (West, 2006). Fungi can infest fishes of all ages and can also prevent

*Corresponding Author Email: kabrmoh@yahoo.com; Tel: +234(0) 8035826075 
successful hatching when it invades fish eggs. Among the numerous aquatic fungi species, Oomycetes have gained more attention because of their effect on fish health (Qureshi et al., 2006). Even though every freshwater fish is exposed to at least one species of fungi during its lifetime, only stressed and poorly fed fishes are more susceptible to fungal infection. Studies of fungi diversity in aquatic environment has been conducted in water and sediment (Doi et al., 2018); on plants (Adamu et al., 2017) and on fishes (Ali, 2015; Angahar, 2016; Atef et al., 2016) as they have reported to cause serious diseases in freshwater fishes. Therefore, the present study was conducted to determine the presence of bacteria and fungi associated with freshwater fishes sampled from River Mijawal, Nasarawa, Nasarawa State Nigeria.

\section{MATERIALS AND METHODS}

The study was carried out at Mijawal River, Nasarawa, Nasarawa State (Plate 1); which is located in the western senatorial district of Nasarawa State. The fish samples were collected aseptically from the landing site of the River and where identified with fish identification key (Olaosebikan and Raji, 2004). The fishes were swabbed with sterile swab stick on the skin; the swab stick was placed in a normal saline solution and transported to Departments of Zoology and Microbiology Laboratories, Nasarawa State University Keffi for further analyses. Sampling was conducted for three months (October to December, 2019).

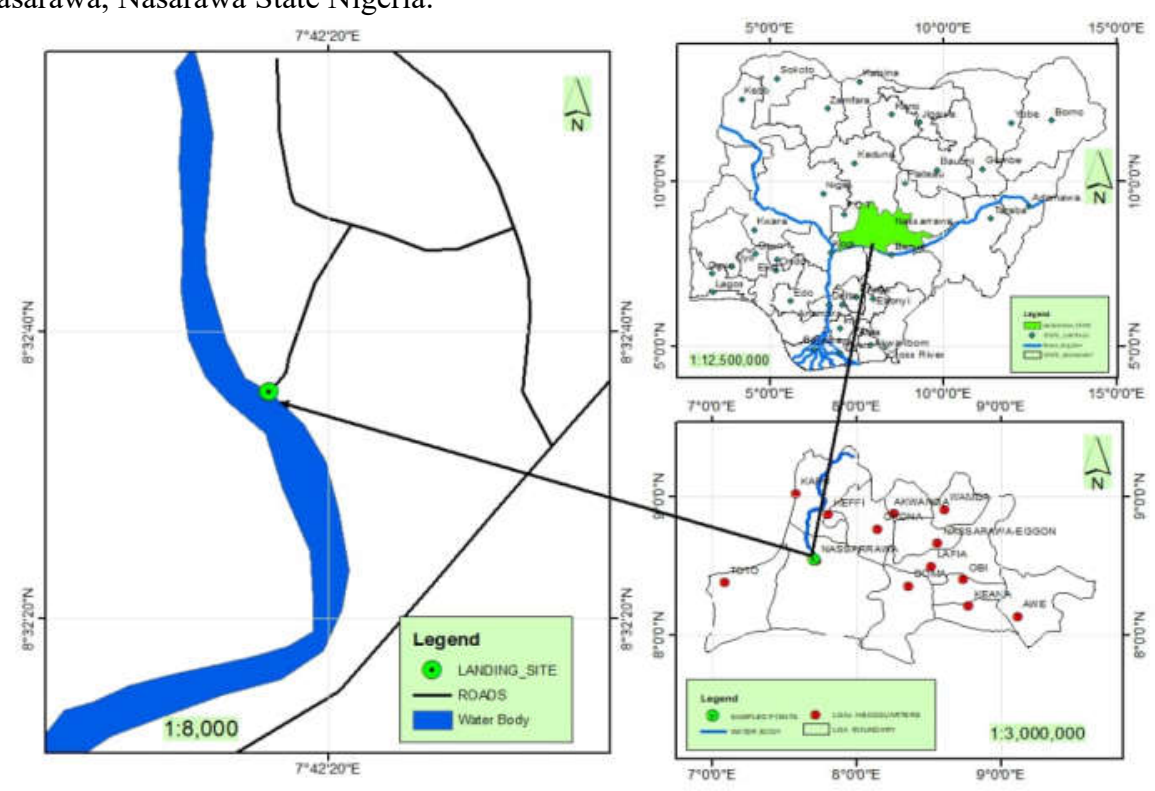

Plate 1. Pictorial representation of the location and sampling site in River Mijawal, Nassarawa State

Bacteriological Analysis: Ten (10) fold serial dilution of the sample was prepared from which $0.1 \mathrm{ml}$ was plated into a sterile Petri dish. Nutrient agar (Titan Biotech) which was prepared according to the manufacturer's specification was poured onto a sterile Petri dish containing $0.1 \mathrm{ml}$ of the sample using pour plate technique.

The plates were then incubated at $37^{\circ} \mathrm{C}$ for 24 hours to obtain mixed culture. Isolated colonies were recorded and purified to obtain pure culture by repeated subculturing on fresh media used for primary isolation as described by Chikozie (2015). Pure stock cultures obtained were inoculated on nutrient agar slant and preserved in the refrigerator at $4^{\circ} \mathrm{C}$ until needed for further characterization and identification.
Characterization and identification of bacterial isolates: Bacterial isolates were characterized by their morphological/macroscopic and microscopic characteristics and identified further by biochemical tests (catalase, coagulase, urease, citrate, oxidase, indole, methyl-red, glucose, lactose and sucrose) as described by Cheesebrough (2000) and Adeoye, (2007).

Isolation and Identification of Fungi: Potato Dextrose Agar (PDA) was used and prepared in accordance to the Manufacturer's instruction (Accumix ${ }^{\circledR}$ - Tulip Diagnostics (P) Ltd).Dilution factors $10^{-2}$ and $10^{-3}$ were used as stock solution. One $\mathrm{ml}$ of each dilution was aseptically taken from the suspension and transferred into sterile Petri dishes. Then Potatoes Dextrose Agar (PDA) was poured into the Petri dishes 
containing the suspension and $1 \mathrm{ml}$ of chloramphenicol. The plates were swirled gently to allow even distribution of the sample in the medium and were incubated at room temperatures $\left(28 \pm 2^{\circ} \mathrm{C}\right)$ for 24 hours. From the culture obtained, sub-culturing was made to get the pure culture of each fungus isolated. Fungi isolated were identified using Fungi Families of the world mycological monographs by Samson et al. (2004). Isolates were studied macroscopically by colony shape, size, colour and growth pattern. Slides were prepared from each colony and stained with $0.05 \%$ Trypan blue in lacto phenol. The slides were observed under microscope. The existing septate wall, sexual organ structure, size and arrangement of spores were also examined and recorded. The fungi species were identified with the help of available fungi identification keys and literature (Willoughby, 1994).

\section{RESULTS AND DISCUSSION}

The data obtained from the sampling periods, revealed the dominant fish species as Mormyrus tapirus, Mormyrus rume, Labeo senegalensis and Tilapia zillii. While Chysichthys aluuensis, Chelathiups bibie, Barbus callipterus, Synodontis vermiculatus, Clarias angullaris and Mormyrus hasselgusti in two sampling periods. However, the species of Momyrus senegalensis, Clarias gariepinus and Raiamas senegalensis were only present once during the sampling period as presented in Table 1. The composition of fish species in this study was lower than those reported by Mandal et al. (2009). However, the decline may be attributed to increased fishing pressure and habitat destruction as report by Emmanuel and Ikusemiju (2005). Similarly, the decline in catch, may also be attributed to the season (dry) of the catch which is characterized by poor water quality, reduced water level and high temperature (Lawson and Olusanya, 2010). Under these conditions, migrations of the species of fish may be responsible for the low catch. However, the findings of this study was in line with the reports of Austin, (2006) who reported eleven (11) species belonging to seven (7) families. Higher abundance of the family Cichlidae may be due to their high level of adaptability to a high range of conditions. According to Terentjeva et al. (2015), Cichlidae are rare in areas where they are competitively disadvantaged especially in areas where they co-exist with larger families (Okomoda et al., 2013).

Table 1: Fish species sampled from River Mijawal during the sampling periods

\begin{tabular}{|c|c|c|c|c|}
\hline \multirow[t]{2}{*}{ Families } & \multirow[t]{2}{*}{ Species } & \multicolumn{3}{|c|}{ Sampling Period } \\
\hline & & October & November & December \\
\hline \multirow[t]{4}{*}{ Mormyridae } & Mormyrus tapirus & + & + & + \\
\hline & Mormyrus senegalensis & + & - & - \\
\hline & Mormyrus rume & + & + & + \\
\hline & Mormyrus hasselqusti & + & + & - \\
\hline \multirow[t]{2}{*}{ Clariidae } & Clarias gariepinus & - & + & - \\
\hline & Clarias angularis & + & - & + \\
\hline Mochokidae & Synodontis vermiculatus & - & + & + \\
\hline \multirow[t]{4}{*}{ Cyprinidae } & Barbus calipterus & - & + & + \\
\hline & Labeo senegalensis & + & + & + \\
\hline & Raiamas senegalensis & + & - & - \\
\hline & Chelathiops bibie & + & - & + \\
\hline Cichlidae & Tilapia zillii & + & + & + \\
\hline Claroteidae & Chysichthys aluuensis & + & + & - \\
\hline
\end{tabular}

A total number of thirteen (13) bacterial isolates were identified from the fishes during the sampling period as shown in Table 2. Amongst these bacteria, eight were gram negative and the other five were gram positive. From the gram positive bacteria isolated, it was observed that Staphylococcus $\mathrm{sp}$ occurred more frequent while Enterococcus sp and Micrococcus sp occurred less frequent. Also amongst the gram negative bacteria isolated, Proteus vulgaris, Klebsiella sp and $E$. coli appeared more frequent while Serratia mercescens appeared least during the sampling periods as shown in Table 3.

The number of occurrence of bacterial isolates (Fig 1) revealed that Staphylococcus spp was recorded to be the highest, followed by Bacillus spp while the lowest was recorded in Serratia mercescens. Based on the frequency of occurrence, it was observed that Tilapia zillii recorded the highest value of $16.67 \%$ while the least was recorded in Raiamas senegalensis (2.78\%) as shown in Fig 2. 
Table 2. Identification of bacterial isolates from sampled fishes in River Mijawal during the sampling period.

\begin{tabular}{|c|c|c|c|c|c|c|c|c|c|c|}
\hline \multirow[t]{2}{*}{ Microorganisms } & \multicolumn{7}{|c|}{ Biochemical Tests } & \multicolumn{3}{|c|}{ Sugar fermentation } \\
\hline & 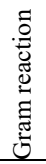 & 离 & 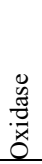 & 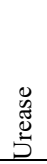 & 荀 & 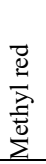 & $\begin{array}{l}\frac{0}{\circ} \\
\frac{0}{\Xi}\end{array}$ & $\begin{array}{l}\mathscr{D} \\
0 \\
0 \\
0 \\
0 \\
0\end{array}$ & 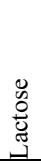 & $\begin{array}{l}\mathscr{D} \\
\mathscr{0} \\
\stackrel{0}{0} \\
\tilde{\Xi} \\
\tilde{S}\end{array}$ \\
\hline Bacillus spp & + & + & + & + & + & - & - & + & + & + \\
\hline Micrococcus sp & + & + & - & + & - & - & - & - & - & - \\
\hline Staphylococcus sp & + & + & - & + & + & + & - & + & + & + \\
\hline Enterococcus sp & + & - & - & - & - & - & - & + & + & + \\
\hline L. monocytogenes & + & + & - & - & - & + & - & + & + & + \\
\hline Pseudomonas sp & - & + & + & - & + & - & - & - & - & - \\
\hline Aeromonas sp & - & + & + & - & + & - & - & + & - & - \\
\hline Serrate mercescens & - & + & - & + & + & - & - & + & - & + \\
\hline Proteus sp & - & + & - & - & + & + & - & + & - & - \\
\hline Salmonella sp & - & + & - & - & - & + & - & + & - & - \\
\hline E. coli & - & + & - & - & - & + & + & + & + & - \\
\hline Klebsiella $\mathrm{sp}$ & - & + & - & + & + & - & - & + & + & + \\
\hline Enterobacter $\mathrm{sp}$ & - & + & - & - & + & - & - & + & - & - \\
\hline
\end{tabular}

Table 3: Total number of Bacterial isolated during the sampling periods

\begin{tabular}{|c|c|c|c|c|}
\hline \multirow[b]{2}{*}{ Bacteria isolates } & \multicolumn{3}{|c|}{ Sampling Period (Monthly) } & \multirow{2}{*}{$\begin{array}{l}\text { Number of } \\
\text { occurrence }\end{array}$} \\
\hline & October & November & December & \\
\hline Bacillus spp & + & + & + & 8 \\
\hline Micrococcus sp & + & + & + & 5 \\
\hline Staphylococcus sp & + & + & + & 12 \\
\hline Enterococcus $\mathrm{sp}$ & + & + & + & 3 \\
\hline L. monocytogenes & + & + & + & 5 \\
\hline Pseudomonas $\mathrm{sp}$ & + & + & + & 9 \\
\hline Aeromonas sp & + & + & + & 9 \\
\hline Serrate mercescens & + & - & + & 12 \\
\hline Proteus sp & + & + & + & 3 \\
\hline Salmonella sp & + & + & + & 7 \\
\hline E. coli & + & + & + & 10 \\
\hline Klebsiella $\mathrm{sp}$ & + & + & + & 12 \\
\hline Enterobacter sp & + & + & + & 5 \\
\hline
\end{tabular}

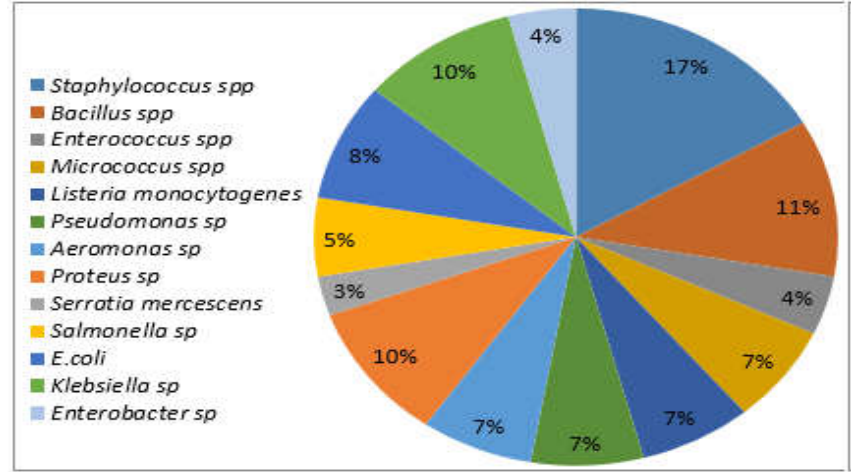

Fig. 1: Percentage frequency of bacterial isolates during the sampling period in River Mijawal, Nassarawa

It was observed in this study, that Tilapia zillii and Mormyrus rume recorded the most frequent bacterial isolate which was similar to the work of Musefiu et al. (2011) on bacteria flora of Clarias gariepinus and Oreochromis niloticus. In most cases fresh fish flora are mainly bacteria. Among all the bacteria species isolated, Pseudomonas sp, Serratia sp, Salmonella, Aeromonas sp, Proteus sp and Klebsiella sp and E. coli from the freshwater fishes sampled from River
Mijawal; Pseudomonas are well-known fish specific spoilage bacteria and their abundance in fish may led to rapid fish spoilage processes that may causes changes in fish meat quality and makes fish unfit for human consumption (Austin, 2006). Studies have shown that Serratia sp. is present in the environment, plant surfaces, soils and water (Blackburn, 2006). Thus their isolation in fish samples. The bacteria are able to grow in an environment that is unsuitable for 
other microbial growth and also contribute to spoilage of foods (Austin, 2006). Among the 13 bacterial species, 8 species were gram negative while 5 were gram positive as Austin (2006) reported 3 species of gram negative bacteria; Micrococcus, Staphylococcus and Bacillus sp. with five (5) genera including Acinetobacter sp, Aeromonas sp, Enterobacter sp, Alcaligenes sp, Moraxella sp and Pseudomonas sp which is similar to the findings of the present study. Similarly Amande and Nwaka (2013), observed the presence of bacteria species such as; Streptococcus, E. coli, Salmonella sp, Staphylococcus sp, Vibrio sp, Pseudomonas sp, Serrati sp, Klebsiella sp, Enterococcus sp and Proteus sp which is also in conformity with bacteria isolated in this work. Based on the percentage frequency of occurrence, the presence of Salmonella sp indicates faecal contamination of the water from which the fishes were harvested which is in line with the work of Elsherif (2004) who reported the isolation of some pathogenic organism such as Salmonella sp, E. Coli and potential pathogenic organisms such as Klebsiella sp, Citrobacter sp and Proteus sp. Abdelhamed et al. (2006) reported that the isolation of Salmonella sp and E. coli from the fish samples indicates faecal contamination of the water resulting from the livestock manure that is being added to the fish ponds as feed.
Bacillus spp on the other hand are known to cause a wide range of infectious diseases including abscesses, bacterimia/Septicimia, wound and food borne infections, ear infections, endocarditis, meningitis, ophthalmitis, Osteomyelitis, peritonitis and respiratory and urinary infections, (Morales et al., 2004). Listeria monocytogenes is widespread in the environment and humans can be exposed to the bacteria in various ways, though many persons remain symptomless. The diversity of potential pathogens from the samples of fish is of concern, particularly at a time when many in our communities are immunologically compromised as a result of various illnesses. The fungi isolated during the sampling periods are presented in Table 4. Five (5) isolates were identified from the sampled fishes based on their morphological examination (Table 5). The highest cumulative average of fungi load on the identified fishes was recorded in Chysichthys aluuensis as $4.00 \times 10^{5} \mathrm{cfu} / \mathrm{ml}$, while the least values $\left(1.00 \times 10^{5} \mathrm{cfu} / \mathrm{ml}\right)$ were recorded in Synodontis vermiculatus and Mormyrus senegalennsis as presented. Table 6 reveals the occurrence of different fungal isolates per fish and it was observed that Rhizopus $s p$ was the most frequent isolate whilst Chysichthys aluuensis recorded the highest number of fungal isolates on the skin.

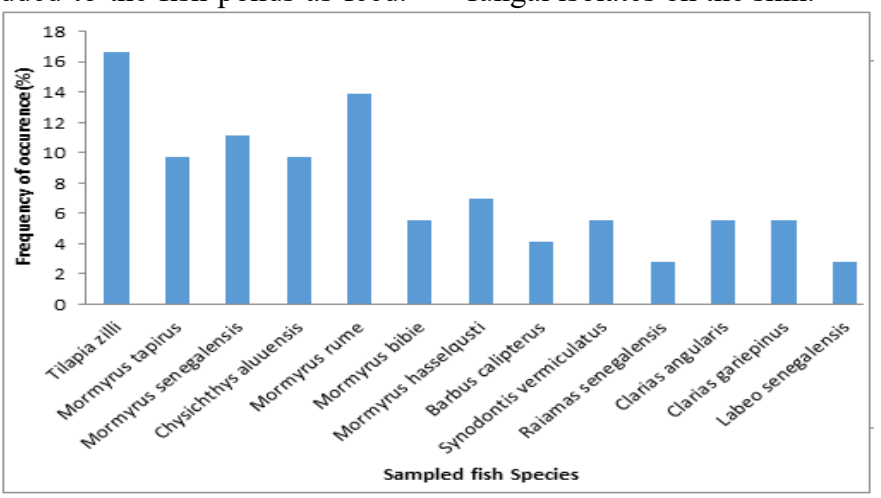

Fig. 2: Frequency of occurrence of bacteria isolated from identified fishes in River Mijawa Nassarawa

Table 4: Fungal load on the skin of identified fishes from River Mijawal, Nasarawa.

\begin{tabular}{l|l|l|l|c}
\hline \multirow{2}{*}{\multicolumn{1}{c}{ Fish Sample }} & \multicolumn{3}{c|}{$\begin{array}{c}\text { Sampling periods (monthly) } \\
\text { Fungi Colony in CFU/ml x 10 }\end{array}$} & $\begin{array}{c}\text { Cumulative } \\
\text { Average } \\
\text { CFU/ml x10 }\end{array}$ \\
\cline { 2 - 4 } & October & November & December & CFU \\
\cline { 2 - 4 } Tilapia zillii & 3.00 & 4.00 & - & 3.50 \\
Mormyrus tapirus & 2.00 & 2.00 & - & 2.00 \\
Mormyrus senegalensis & - & - & 1.00 & 1.00 \\
Chysichthys aluuensis & - & - & 4.00 & 4.00 \\
Mormyrus rume & 3.00 & - & 4.00 & 3.50 \\
Chelathiops bibie & 2.00 & - & 4.00 & 3.00 \\
Mormyrus hasselqusti & - & 2.00 & - & 2.00 \\
Barbus calipterus & 2.00 & 3.00 & - & 2.50 \\
Synodontis vermiculatus & - & 1.00 & - & 1.00 \\
Raiamas senegalensis & - & - & 3.00 & 3.00 \\
Clarias angularis & 2.00 & - & - & 2.00 \\
Clarias gariepinus & - & - & 3.00 & 3.00 \\
Labeo senegalensis & 3.00 & 3.00 & - & 3.00 \\
\hline
\end{tabular}


Table 5: Characterization and identification of fungi isolates from identified fishes in River Mijawal, Nassarawa

\begin{tabular}{|c|c|c|}
\hline \multicolumn{2}{|l|}{ Morphological Characterization } & \multirow[t]{2}{*}{ Probable Fungi } \\
\hline Macroscopic & Microscopic & \\
\hline $\begin{array}{l}\text { Surface-colonies like yellow to } \\
\text { white hyphae, turning black with } \\
\text { the formation of hyphae }\end{array}$ & $\begin{array}{l}\text { Hyphae are septate, hyaline } \\
\text { and conidiophores are long and } \\
\text { globose at the tip }\end{array}$ & $\begin{array}{l}\text { Aspergillus } \\
\text { niger }\end{array}$ \\
\hline $\begin{array}{l}\text { Surface-texture velvety to } \\
\text { powdery, green, blue-green or gray } \\
\text { green on surface. } \\
\text { Reverse; usually white to } \\
\text { yellowish sometimes red or brown. }\end{array}$ & $\begin{array}{l}\text { Hyphae septate, hyaline, } \\
\text { conidiophores simple or } \\
\text { branched phialides grouped in } \\
\text { brush like clusters (penicilli) at } \\
\text { the ends of the conidiophores. }\end{array}$ & Penicillium $s p$ \\
\hline $\begin{array}{l}\text { Surface-texture deeply cottony } \\
\text { white becoming gray brown on } \\
\text { surface } \\
\text { Reverse:pale white }\end{array}$ & $\begin{array}{l}\text { Hyphae broad, not or scarcely } \\
\text { septet }\end{array}$ & Rhizopus sp \\
\hline $\begin{array}{l}\text { Surface-o-white to cream coloured } \\
\text { colonies with butryrous texture } \\
\text { with a velvety, suede like or } \\
\text { ground glass/matt appearance }\end{array}$ & $\begin{array}{l}\text { Clear hyaline, septate hyphae. } \\
\text { Produce chains of } \\
\text { arthroconidia. }\end{array}$ & $\begin{array}{l}\text { Geotrichum } \\
\text { candidum }\end{array}$ \\
\hline $\begin{array}{l}\text { Surface-fluffy white tufts, green } \\
\text { tufts may develop within the } \\
\text { colony, } \\
\text { Reverse; typical light tan to yellow } \\
\text { or pale orange. }\end{array}$ & $\begin{array}{l}\text { Septate hyaline hyphae, } \\
\text { conidiophores are short and } \\
\text { branching. Phialides are flask } \\
\text { shaped. Conidia are ellipsoidal. }\end{array}$ & $\begin{array}{l}\text { Trichoderma } \\
\text { viridae }\end{array}$ \\
\hline
\end{tabular}

Table 6: Occurrence of Fungal isolates identified from freshwater fishes sampled from River Mijawal, Nasarawa.

\begin{tabular}{|c|c|c|c|c|c|}
\hline Fish Samples & 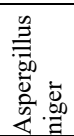 & 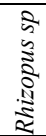 & 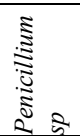 & 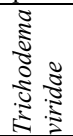 & 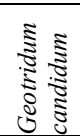 \\
\hline Tilapia zillii & + & + & - & + & - \\
\hline Mormyrus tapirus & - & - & + & - & + \\
\hline Mormyrus senegalensis & - & + & - & - & - \\
\hline Chysichthys aluuensis & + & + & - & + & + \\
\hline Mormyrus rume & + & - & - & + & - \\
\hline Chelathiops bibie & + & - & + & - & - \\
\hline Mormyrus hasselqusti & - & + & + & - & - \\
\hline Barbus calipterus & - & + & - & + & - \\
\hline Synodontis vermiculatus & - & + & - & - & - \\
\hline Raiamas senegalensis & - & + & + & + & - \\
\hline Clarias angularis & + & - & + & - & - \\
\hline Clarias gariepinus & + & - & + & + & - \\
\hline Labeo senegalensis & + & + & + & - & - \\
\hline Total Number of isolates & 7 & 8 & 7 & 6 & 2 \\
\hline
\end{tabular}

Pathogenic Fungi isolates such as Aspergillus niger was isolated in this study which are higher than that reported by Ali, (2015). Reports have revealed that the fungi are mostly frequent in fishes (Ali, 2015; Doi et al., 2018). De Hoog et al. (2000) had described Aspergillus niger in water as causative agents of kidney, liver disorder, allergy, burns, otitis media and increase risk of invasive infections. A. niger is a common allergen and may cause opportunistic invasive respiratory infection in hospitalized immunized patients (De Hoog et al., 2000). According to Doctor, (2007), fungi are reported to infest fish when bacteria infestations is present; thereof, they are reported as opportunistic parasites that are able to take advantage of damaged or stressed fishes. The high quantum of fungal pathogen recorded in this study may be an indication of high bacteria or other pathogens present on the surface of the identified sampled fishes which as supported by researcher (Junaid et al., 2010). The source of these fungal pathogens may be associated with anthropogenic activities that occur around the water as well as the presence of bacterial isolates. The presence of Penicillium $s p$ in the sampled fishes had shown that the fungal is most associated with fish as supported by the study conducted by Momeni et al. (2014), who reported that Penicillium $s p$ caused $22 \%$ mortality of fish eggs which is supported by the report of Iqbal and Saleemi (2013) as an indication that as these parasites increase in their number, they are likely to affect fish production in the wild, thereby affecting fish harvest from the river. The isolation of yeast from this study is revealed that they are used for supplementation based diets. 
Conclusion: In conclusion, this research has brought to light, the bacterial and fungal species associated with fishes at River Mijawal Nasarawa. The presence of these microbes in large population indicates high levels of faecal contamination in the River which are also potentially pathogenic to human. Hence, adequate measures should be taken in the examination of fish, especially for the presence of pathogens, during handling, storage and up to the very point of consumption is needed for the protection and maintenance of community health by keeping foodborne diseases to a minimum.

\section{REFERENCES}

Abdelhamid, AM; Gawish, MM; Soryal, KA (2006). Comparative study between desert cultivated and natural fisheries of mullet fish in Egypt. II Microbiological concern. Journal of Agricultural Science Mansoura University. 31:5681-7.

Adams, AJ; Tobias, WJ (1999). Red mangrove proproot habitat as a finfish nursery area: a case study of Salt River Bay, St. Croix, USVI. Proc Gulf Caribb Fish Inst, 22-46.

Adamu, KM; Aliyu-Paiko, M; Ikomi, RB; Suleiman, SA; Ahmed, IB; Mamman, R; Mohammed, SSD (2017). Evaluating the associate microbial organisms, fish feed utilization potential and feedstock in biogas production of water hyacinth, FUTA Journal of Research in Sciences, 13(1): 24 $-38$

Adeoye, A (2007). Medical Laboratory Practice, 1st Edition, FEMCO Publishers limited, Lagos, Nigeria, 153pp

Ali, HH (2015). Isolation and Identification of Pathogenic Fungi from Carp fish in Suliamania Province, Global Journal of Bio-Science and Biotechnology, 4(4): 356 - 363

Amande, TJ; Nwaka, SU (2013). Bacterial flora of African catfish (Clarias gariepinus) harvested from ponds in Uyo South-south Nigeria. IOSR Journal of Environmental Science Toxicology and Food Technology, 5(30):72-76.

Angahar, LT (2016). Prevalence of Saprolegniasis in Fish Farms in Gboko, Nigeria. American Journal of Animal and Veterinary Research, 1: 1-8.

Atef, HA; El Shafei, HM; Mansour, MK; Snosy, SA; Abo-Zaid, KF (2016). Effect of Microbiological contamination and Pollution of water on the Health status of fish. European Journal of Academic Essays, 3 (5): 178-192.

Austin, B (2006). The bacterial microflora of fish, revised. The Scientific World Journal, 6: 931-945.

Ayanwu, DC; Udedibie, ABI; Osuigwe, DI; Offor, JI (2015). Haematological Responses of Hybrid Catfish fed dietary levels of Ipeomea batatas leaf meal. American Journal of Research Communications 3(9): 49-58.

Cahill, MM (1990). Bacterial flora of fishes: A review. J Microb Ecol; 19:2141.

Cheesbrough, M (2000). District laboratory practice in tropical countries. Parts 2 published by Cambridge University Press. Pg 13-7

Chikozie, IO (2015). Microbiological laboratory Manual, Microtrend Digital Press, Nigeria Ltd., pp21-29.

De Hoog, GS; Guarro, J; Gene, J; Figueras, MJ (2000). Atlas of Clinical Fungi. Centrealbureau voor schimmeclutures, Utretcht, The Netherlands.

Doctor, IF (2007). Common fish diseases. Retrieved August, 2006 from http:/www.fishdoc.co.uk/disease/trichodina.htm.

Doi, SA; Pinto, AB; Canali, CC; Polezel, DR; Chinellato, RAM; de Oliveira, AJFC (2018). Density and diversity of filamentous fungi in the water and sediment of Araçá bay in São Sebastião, São Paulo, Brazil, Biota Neotropica 18(1): e20170416, 1-9

El-Sherif, MS; Elfeky, A; Amal M (2004). Effect of ammonia on Nile tilapia (O. niloticus) performance and some haematological and Histological measures. Animal Prod and Fish Res. Dept Egypt. International Symposium on Tilapia in Aquaculture. 513.

Emmanuel, BE; Ikusemiju, K (2005). Variations in Castnet Catch in a Tropical Brackish Water Pond. Journal of Science Technology and Environment; 5(1\&2):6-14.

FAO (2009). The state of world fisheries and aquaculture 2008. Rome, Italy: Food and Agriculture Organization of the United Nations. See http://www.fao.org/fishery/sofia/en. 
Hussain, MK; Islam, KT; Hossain, MD; Rahman, MH (2011). Environmental impact assessment of fish diseases on fish production. J. Sci. Foundation. 9(1\&2): 125-131.

Iqbal, Z; Saleemi, S (2013). Isolation of pathogenic fungi from a freshwater commercial fish, Cotta cotta (Hamilton) Scl.mt (Lahore), 25(4):851-855. Iranian Journal of Fisheries Sciences.

Jimoh, WA; Ayeloya, AA; Oladele-Bukola, MO; Adebayo, MD; Azeez, AF; Salami, SR (2014). Isolation of fungi infesting smoked African catfish from markets in Ibadan, Nigeria, Nigerian Journal of fisheries and Aquaculture. 2(2):13-17

Junaid, SA; Olarubofin, F; Olabode AO (2010). Mycotic contamination of stockfish sold in Jos, Nigeria. Journal of yeast and fungal Res. 1: 136141.

Lawson, OE; Olusanya, OM (2010). Fish Diversity in three Tributaries of River Ore, South

Limburg, KE; Hughes, KM; Jackso, DC; Brain, CZ (2011). Human population increase, Economic Growth and Fish conservation collision course or savvy steward ship. Fisheries, 36:27-34.

Mandal, MS; Mahitosh M; Octavio LF (2009). Identification and structural insights of three novel antimicrobial peptides isolated from green coconut water. Journal of peptides 30(4): 633-7 DOI: 10.1016/J.Peptides.12.001.

Momeni, SM; Asgari, MR; Khamesipour, F; Raissy, M (2014). Prevalence of Argulus foliaceus and Fungal infections in some Ornamental fishes [Discus (Symphysodon discus), Dwarf Gourami (Trichogaster lalius) and Guppy (Poecilia reticulata)] in Isfahan City of Iran. Kafkas Univ Vet Fak Derg , 5, 817-820.

Morales, AE; Perez-Jimenez, A; Hidalgo, MC; Abellan, E; Carenete, G (2004). Oxidative stress and antioxidant defences after prolonged starvation in Dentex dentex liver. Comp. Biochem. Physiol. 139C: 153-161.

Musefiu, TA; Emikpe, BO; Adedeji, OB (2011). Isolation and identification of aerobic bacteria flora of the skin and stomach of wild and cultured Clarias gariepinus and Oreochromis niloticus from Ibadan, Southwest Nigeria. J. Appl. Sci. Res. 7(7): 1047-1051.
Okomoda, VT; Ataguba, GA; Ayuba, VO (2013). Haematological response of Clarias gariepinus fingerlings exposed to acute concentrations of Sunsate. Journal of Stress physiology and Biochemistry. 9(2):271-278.

Olaosebikan, BD; Raji, A (2004). "Field Guide to the Nigerian Fresh water Fishes". $2^{\text {nd }}$ Edition Federal College of Freshwater Fisheries Technology, New Bussa, Nigeria. 111p.

Olugbojo, JA; Ayoola, SO (2015). Comparative studies of bacteria load in fish species of commercial importance at the Aquaculture Unit and Lagoon Front of the University of Lagos. International Journal of Fisheries and Aquaculture, 7(4): 37-46.

Philips, S; Wallbridge, A (1977) The mycoflora associated with dry tropical Fish In "Handling processing and Marketing of tropical fish" Tropical produces Institute, London Pp,353- 356.

Qureshi, JA; Najar, AM; Salmon, R; Amioria, S (2006). Common fish species of Wular Lake, Kashmir. Their morphometric contextual studies. Fishing chimes. 25:133-135.

Samson, RA; Horksta, ES; Frisvad, J; Fitenborg, O (2004). Introduction to food and airborne fungi, sixth edition 282pp.

Terentjeva, M; Eizenberga, I; Novoslavskij, A; Strazdiṇa, V; Valciṇa, O; Ošmjana, J; Bērziṇš, A (2015) Bacterial microflora of freshwater fish originated from Usmas Lake in Latvia. The Journal of Microbiology, Biotechnology and Food Sciences, Vol. 4, p. 74-77.

West, PV (2006). Saprolegnia paracitica, an oomycete pathogen with a fleshy appetite: New challenges for an old problem, Mycologist. 20(3): 99-104.

Willoughby, LG (1994). Fungi and Fish Disease Pisces. Press Stirl. UK. pp 57 